\title{
CELIAKIJOS IR 1 TIPO CUKRINIO DIABETO RYŠYS
}

\author{
Kamilè Antanavičiūtė, Rūta Šarkūnaitė \\ Lietuvos sveikatos moksly universitetas, Medicinos akademija, Medicinos fakultetas
}

Raktažodžiai: celiakija, 1 tipo cukrinis diabetas, komorbidiškumas, dažnis, gydymas, begliutenè dieta.

\section{Santrauka}

Celiakija - tai autoimuninis plonųjų žarnų uždegimas, sukeltas Th-1 limfocitų hiperreakcijos ị kviečiuose, rugiuose bei miežiuose esantị baltymą gliadiną bei lemiantis gleivinès gaurelių atrofiją, kriptų hiperplaziją ir malabsorbciją. Nustatyta, jog sergantys šia liga yra linkę sirgti 1 tipo cukriniu diabetu (CD), nes abi ligas sieja bendra genetinè kilmè. Pasaulyje celiakijos dažnis 1 tipo CD sergančiujų populiacijoje yra nuo 5 iki 16 kartų didesnis, nei bendrojoje. Dažnai celiakija sergant 1 tipo CD yra asimptominè, tačiau, jos negydant, stebima bloga glikemijos kontrolè, didesnè kardiovaskulinių ligų rizika, didèja diabeto komplikacijų pasireiškimo rizika jaunesniame amžiuje. Šiuo metu nèra bendrosios nuomonès dèl celiakijos diagnozavimo ir gydymo taktikos sergant 1 tipo CD. Pagrindinis celiakijos gydymo būdas bendrojoje populiacijoje yra ilgalaikè begliutené dieta, todèl šis gydymas rekomenduojamas ir sergantiesiems abiem minètomis ligomis, tačiau laikantis šios dietos, sergantieji 1 tipo CD turi būti prižiūrimi gydytojų endokrinologo ir dietologo.

Tyrimo tikslas - išanalizuoti mokslinejje literatūroje aprašytą celiakijos ir 1 tipo cukrinio diabeto ryšįi.

Tyrimo metodika. Atlikta sisteminé literatūros apžvalga, naudojantis PubMed, ScienceDirect duomenų bazèmis, nagrinejjant straipsnius apie celiakinę ligą ir 1 tipo cukrini diabetą. Atrinkti ir išanalizuoti 23 straipsniai.

Rezultatai. Atlikti tyrimai patvirtina didesnị celiakijos pasireiškimo dažnį tarp sergančiųjų 1 tipo $\mathrm{CD}$, lyginant su sveikąja populiacija.

\section{Ivadas}

Celiakija - tai autoimuninis plonųjų žarnų uždegimas, sukeltas Th - 1 limfocitų hiperreakcijos ị kviečiuose, rugiuose bei miežiuose esantį baltymą gliadiną, sudetyje turintị gliutamino ir prolino aminorūgščių. Šiam balymui patekus ị organizmą, B limfocitai, aktyvinti Th-1 limfocitų, išski- ria specifinius imunoglobulinus - antikūnius prieš audinių transgliutaminazę (aTG2), endomiziumą (EmA) ir deamidintą gliadino peptidą (aDGP) [1] bei aktyvina uždegiminių citokinų (gama interferono, tumoro nekrozès faktoriaus) išsiskyrimą. Tai sukelia gleivinès gaurelių atrofiją, kriptų hiperplaziją ir klinikini malabsorbcijos pasireiškimą. Celiakija yra viena iš dažniausiai nustatomų žarnyno uždegiminių ligų ir jos paplitimas siekia iki 1 proc. visame pasaulyje. Vis dažniau nustatoma, jog sergantys šia liga yra linkę sirgti ir kitomis autoimuninèmis ligomis: skydliaukès sutrikimais (Hashimoto tiroiditas, Grave's liga), reumatoidiniu artritu ir, dažniausiai, 1 tipo cukriniu diabetu (CD) [2]. 1 tipo $\mathrm{CD}$ - tai autoimuninè kasos beta ląstelių destrukcija, pasireiškianti absoliučiu insulino stygiumi. Abi šios ligos pažeidžia įvairias organų sistemas, stipriai paveikia sergančiojo gyvenimo kokybę bei galimai didina mikrovaskulinių diabeto komplikacijų išsivystymo riziką [3].

Tyrimo tikslas - išanalizuoti mokslinèje literatūroje aprašytą celiakijos ir 1 tipo cukrinio diabeto ryšị.

\section{Tyrimo medžiaga ir metodai}

Atlikta sisteminė literatūros apžvalga, naudojantis PubMed, ScienceDirect duomenų bazėmis, nagrinejjant straipsnius apie celiakinę ligą ir 1 tipo cukrinị diabetą. Atrinkti ir išanalizuoti 23 straipsniai.

\section{Tyrimo rezultatai}

Celiakijos ir 1 tipo cukrinio diabeto etiopatogenezinis ryšys. Celiakijos etiopatogenezè susideda iš keleto veiksnių: genetinès predispozicijos, autoimuninio atsako bei aplinkos veiksnio - gliuteno. Pastaraisiais metais atliekami tyrimai rodo, jog celiakiją ir 1 tipo CD sieja vienas iš patogenezinių veiksnių: bendra genetinè kilmè. Už 1 tipo CD pasireiškimą atsakingas II žmogaus leukocitų antigenų klasės HLA (angl. Human leukocyte antigens class II) DR, DQ ir DP lokusai, esantys 6p21 chromosomoje. Didžiausia 1 tipo CD rizika tenka asmenims, kurių šioje chromosomoje yra DR3-DQA1*0501 - DQB1*02:01 ir DR4-DQAI*03:11 - DQB1*03:02 haplotipu aleliai. Nustatyta, jog tie patys haplotipai atsakingi ir už celiakijos išsivystymą [3-5]. 
Abi ligas sieja ir ne HLA genai: PTPN22 bei CTLA4 [6].

Epidemiologija. Pasaulyje atliktuose tyrimuose celiakijos dažnis 1 tipo CD sergančiųjų populiacijoje yra nuo 5 iki 16 kartų didesnis nei bendrojoje [7]. Pasireiškimo dažnis skirtinguose žemynuose varijuoja. Remiantis histopatologinio tyrimo rezultatais, celiakija sergančiųų 1 tipo $C D$ populiacijoje Europoje pasireiškia nuo 3,2 iki 10,4 proc., Azijoje - 6,2 proc., Australijoje - 7,7 proc., Šiaurès Amerikoje - 1,9 proc., Pietų Amerikoje nuo 1,7 iki 7,1 proc. populiacijos. Didžiausia šiomis ligomis sergančiujų populiacija yra Afrikoje - dažnis varijuoja nuo 10,3 iki 16,4 procento $[4,5,8]$.

Prognostiniai veiksniai. Be anksčiau minètos genetinès predispozicijos, nustatyti prognostiniai veiksniai, leidžiantys prognozuoti tikimybę išsivystyti celiakijai, sergant 1 tipo CD. Remiantis literatūros šaltiniais, moteriška lytis (šansų santykis (ŠS) skirtingoje literatūroje varijuoja tarp 1,26 ir 3,19 ), nustatyta hipotirozè (S̆S varijuoja tarp 2,37 ir 6,4), amžius, kai buvo nustatytas 1 tipo $\mathrm{CD}(\breve{\mathrm{S} S}=0,51$, kai amžius $>10 \mathrm{~m}$. ir ŠS $=1,7$, kai amžius $<5 \mathrm{~m}$.), žemesnis ūgis (ŠS 3,16), celiakijos anamnezè šeimoje ( $\breve{S} S=2,6)$ lemia didesnę celiakijos išsivystymo tikimybę [4,9-13]. Nustatyta, jog sunkesnès celiakijos simptomatikos pasireiškimas bei jaunesnis amžius, kai buvo nustatytas 1 tipo $\mathrm{CD}$, buvo reikšmingi veiksniai, leidžiantys prognozuoti teigiamus celiakijos serologinių tyrimų rezultatus [9].

Diagnostika. 1 tipo CD diagnozè nustatoma atlikus ịprastini glikemijos tyrimą ar, pasireiškus ligos simptomams, - gliukozès tolerancijos méginį. Patvirtinti diagnozę bei nustatyti CD tipą atliekami autoantikūnių tyrimai (anti-IA2, anti-GAD 65, ICA) [6]. Bendrojoje populiacijoje tyrimai dèl celiakijos atliekami tik pasireiškus klinikiniams ligos simptomams: malabsorbcijai, svorio kritimui, dažnai pasikartojantiems pilvo skausmams bei viduriavimui, nenustatytos kilmès geležies stokos anemijai. Nustatant diagnozę, atliekami serologiniai tyrimai: ieškoma aTG2, EmA ir aDGP autoantikūnių. Nors jautriausias ir specifiškiausias tyrimas yra EmA paieška, tačiau, dèl techninio tyrimo sudètingumo, pasaulyje kaip kontrolinis tyrimas atliekamas aTG2 nustatymas kraujyje. Jis tiesiogiai koreliuoja su celiakijos pasireiškimo tikimybe - kuo didesnis aTG2 titras, tuo didesnè celiakijos tikimybė $[7,14]$. Tyrimai turi būti atliekami pacientams nesilaikant begliutenès dietos. Celiakijos diagnostikos aukso standartu laikoma plonujų žarnų gaurelių biopsija ir bioptato histologinis ištyrimas, ypač tais atvejais, kai nustatomi žemi serologinių tyrimų titrai, tačiau yra aiški ligos simptomatika [14].

Kol kas nèra bendrosios nuomonès, kada dèl celiakijos reikia tirti pacientus, sergančius 1 tipo $\mathrm{CD}$. Remiantis Tarptautinès diabeto federacijos (IDF, angl. International Federation of Diabetes) gairemis, pediatrinius pacientus rekomen- duojama tirti iš karto nustačius 1 tipo $\mathrm{CD}$ diagnozę ir kas 5 metus, jei nepasireiškia klinikiniai celiakijos simptomai, tačiau Kanados diabeto asociacijos bei Amerikos gastroenterologijos žurnalo paskelbtose klinikinėse rekomendacijose siūloma diabetu sergančius vaikus ir suaugusiuosius tirti tik esant simptomatikai $[1,15,16]$. Remiantis 2015 metais A. Pham-Short ir kitų mokslininkų atlikta 457 studijų sistemine literatūros analize, dažniausiai (79\% tiriamujų) celiakija buvo nustatyta per 5 metus, 16 proc. tarp $5-10$ metuc, 5 proc. praejus $>10$ metu po 1 tipo CD diagnozavimo [9]. Pastebèta, jog, sergant 1 tipo $C D$, randami reikšmingai žemesni autoantikūnių titrai nei bendrojoje populiacijoje, todèl diagnozès patvirtinimui rekomenduojama atlikti gaurelių biopsiją, nors simptomatika ir nèra stipriai išreikšta ar stebimi žemi serologiniai titrai $[9,17,18]$.

Celiakijos ir 1 tipo CD koreliacijos reikšmè klinikai. Celiakijos simptomatika sergant 1 tipo CD dažnai yra nežymi ir mažai pastebima bei pasireiškia bendrojoje populiacijoje iprastiniais simptomais. Literatūros duomenimis, 1 tipo CD ir celiakija sergančiujjų populiacijoje dažniau pastebimi ryškūs kaulų mineralizacijos sutrikimai bei folinès rūgšties ar geležies stokos anemijos, lyginant su 1 tipo CD pacientais, nesergančiais celiakija $[3,5,19,20]$. Negydant celiakijos, stebima bloga glikemijos kontrolè, dažnesnè hipoglikemija, mažesnis didelio tankio cholesterolio (DTL) kiekis kraujyje bei didesnè širdies ir kraujagyslių ligų rizika. Be to, didèja diabeto komplikacijų rizika jaunesniame amžiuje. Remiantis nagrinèta literatūra, rizika išsivystyti retinopatijai yra $1,263[95 \% \mathrm{Cl} 1,078$ - 1,481], o nefropatijai - 1,359[1,228 - 1,504] didesné sergant 1 tipo CD ir celiakija, lyginant su sergančiaisiais tik $\mathrm{CD}[3,5,6,10]$.

Gydymas. Pagrindinis celiakijos gydymo būdas yra begliutenè dieta. Svarstoma, koks mažiausias gliuteno kiekis galètų būti vartojamas nesukeliant ligos simptomatikos, tačiau bendrosios nuomonès kol kas nèra. Literatūroje aprašytuose tyrimuose rasta, jog gliutenas sukelia hiperergines reakcijas ne tik sergant celiakija, bet ir 1 tipo CD. Lyginant su sveikuju populiacija, sergančiujju 1 tipo $C D$ rasta reikšmingai aktyvesnè $\mathrm{T}$ limfocitu proliferacija ir pro-uždegiminių citokinų gamyba [20]. Dieta, kaip gydymo būdas, rekomenduojama ir sergantiesiems celiakija kartu su 1 tipo $\mathrm{CD}$, tačiau esant nekoreguojamai celiakijai, dalis maisto medžiagų neabsorbuotos pasišalina iš organizmo. Taikant begliutenę dietą, didejja absorbuojamų medžiagų kiekis, todèl didejja ir insulino poreikis. Dèl tos priežasties besilaikantys šios dietos turi būti prižiūrimi gydytojų endokrinologo ir dietologo [21].

Nagrinejjant begliutenès dietos poveikị pacientams, sergantiems simptomine celiakija ir gerai kontoliuojamu 1 tipo $\mathrm{CD}$, nustatytas teigiamas poveikis ịvairiems veiks- 
niams: didèja DTL cholesterolio kiekis, reikšmingai mažeja hipoglikemijų skaičius, HbA1c sumažejja 0,73 procento. Begliutenès dietos taikymas nesant celiakijos simptomų yra kontroversiškas $[6,22,23]$.

\section{Išvados}

Itvairiose šalyse atlikti tyrimai patvirtina didesnị celiakijos dažnį tarp sergančiujų 1 tipo $\mathrm{CD}$, lyginant su sveikaja populiacija. Kadangi sergantiesiems abiem ligomis dažniau pasireiškia besimptomè celiakijos forma, rekomenduojama celiakiją tirti visiems pacientams, sergantiems 1 tipo $\mathrm{CD}$, o nustačius ligą, taikyti daugiadisciplininę priežiūrą.

\section{Literatūra}

1. Rubio-Tapia A, Hill I, Kelly C, Calderwood A, Murray J. ACG clinical guidelines: diagnosis and management of celiac disease. American Journal Gastroenterology 2013;108(5):656-676. https://doi.org/10.1038/ajg.2013.79

2. Kahaly G, Frommer L, Schuppan D. Celiac disease and endocrine autoimmunity - the genetic link. Autoimmunity Reviews 2018;17(12):1169-1175.

https://doi.org/10.1016/j.autrev.2018.05.013

3. DeMelo E, McDonald C, Saibil F, Marcon M, Mahmud F. Celiac disease and type 1 diabetes in adults: is this a high-risk group for screening? Canadian Journal Diabetes 2015;39(6):513-519. https://doi.org/10.1016/j.jcjd.2015.06.006

4. Craig M, Prinz N, Boyle C, Campbell F, Jones T, Hofer S et al. Prevalence of celiac disease in 52,721 youth with type 1 diabetes: international comparison across three continents. Diabetes Care 2017;40(8):1034-1040.

https://doi.org/10.2337/dc16-2508

5. Simmons K, McFann K, Taki I, Liu E, Klingensmith G, Rewers $\mathrm{M}$ et al. Reduced bone mineral density is associated with celiac disease autoimmunity in children with type 1 diabetes. Journal Pediatrics 2016;169:44-48.e1.

https://doi.org/10.1016/j.jpeds.2015.10.024

6. Cohn A, Sofia A, Kupfer S. Type 1 diabetes and celiac disease: clinical overlap and new insights into disease pathogenesis. Current Diabetes Reports 2014;14(8). https://doi.org/10.1007/s11892-014-0517-x

7. Kaur N, Bhadada S, Minz R, Dayal D, Kochhar R. Interplay between type 1 diabetes mellitus and celiac disease: implications in treatment. Digestive Diseases 2018;36(6):399-408. https://doi.org/10.1159/000488670

8. Velasco-Benítez C, Ruíz-Extremera Á, Matallana-Rhoades1 A, Giraldo-Lora S, Ortíz-Rivera C. Prevalence of markers of celiac disease in Colombian children with diabetes mellitus type 1. Colombia Medica 2018:273-279. https://doi.org/10.25100/cm.v49i4.3650

9. Pham-Short A, Donaghue K, Ambler G, Phelan H, Twigg S, Craig M. Screening for celiac disease in type 1 diabetes: a systematic review. Pediatrics 2015;136(1):e170-e176.

https://doi.org/10.1542/peds.2014-2883

10. Vajravelu M, Keren R, Weber D, Verma R, De León D, Denburg $\mathrm{M}$. Incidence and risk of celiac disease after type 1 diabetes: a population-based cohort study using the health improvement network database. Pediatric Diabetes 2018;19(8):1422-1428. https://doi.org/10.1111/pedi.12770

11. Seth A, Singh P, Kumar P, Sajjan S. Coexistence of celiac disease $\&$ type 1 diabetes mellitus in children. Indian Journal Medical Research 2017;145(1):28. https://doi.org/10.4103/ijmr.IJMR_199_15

12. Serena G, Camhi S, Sturgeon C, Yan S, Fasano A. The role of gluten in celiac disease and type 1 diabetes. Nutrients 2015;7(9):7143-7162. https://doi.org/10.3390/nu7095329

13. Parkkola A, Härkönen T, Ryhänen S, Uibo R, Ilonen J, Knip M. Transglutaminase antibodies and celiac disease in children with type 1 diabetes and in their family members. Pediatric Diabetes 2017;19(2):305-313. https://doi.org/10.1111/pedi.12563

14. Garg K, Gupta R. What a practitioner needs to know about celiac disease? Indian Journal Pediatrics 2014;82(2):145-151. https://doi.org/10.1007/s12098-014-1544-y

15. International Diabetes Federation. Other complications and associated conditions. Global IDF/ISPAD guidelines for diabetes in childhood and adolescence. 2011:124-8.

16. Wherrett D, Hout C. Mitchell B, Pacaud D. Type 1 diabetes in children and adolescents. Can J Diabetes 2013;37(Suppl 1):S153-62. https://doi.org/10.1016/j.jcjd.2013.01.042

17. Thong E, Wong P, Dev A, Ebeling P, Teede H, Milat F. Increased prevalence of fracture and hypoglycaemia in young adults with concomitant type 1 diabetes mellitus and coeliac disease. Clinical Endocrinology 2017;88(1):37-43. https://doi.org/10.1111/cen.13488

18. Lewandowska K, Ciepiela O, Szypowska A, Wyhowski J, Głodkowska-Mrówka E, Popko K et al. Celiac antibodies in children with type 1 diabetes - a diagnostic validation study. Autoimmunity 2018;51(2):81-88. https://doi.org/10.1080/08916934.2018.1427226

19. Odeh R, Alassaf A, Gharaibeh L, Ibrahim S, Khdair Ahmad F, Ajlouni K. Prevalence of celiac disease and celiac-related antibody status in pediatric patients with type 1 diabetes in Jordan. Endocrine Connections 2019;8(6):780-787.

https://doi.org/10.1530/EC-19-0146

20. Rohrer T, Wolf J, Liptay S, Zimmer K, Fröhlich-Reiterer E, Scheuing $\mathrm{N}$ et al. Microvascular complications in childhoodonset type 1 diabetes and celiac disease: a multicenter longitudinal analysis of 56,514 patients from the German-Austrian DPV database. Diabetes Care 2015;38(5):801-807.

https://doi.org/10.2337/dc14-0683 
21. Kaur P, Agarwala A, Makharia G, Bhatnagar S, Tandon N. Effect of gluten free diet on metabolic control and anthropometric parameters in type 1 diabetes with subclinical celiac disease: a randomized controlled trial. Endocrine Practice 2020.

https://doi.org/10.4158/EP-2019-0479

22. Srivastava A, Chaturvedi S, Dabadghao P, Mathias A, Shukla U, Singh U et al. Prevalence of celiac disease in Indian children with type 1 diabetes. Indian Journal of Gastroenterology 2016;35(5):372-378.

https://doi.org/10.1007/s12664-016-0692-6

23. Egner W, Shrimpton A, Sargur R, Patel D, Swallow K. ESPGHAN guidance on coeliac disease 2012. Journal Pediatric Gastroenterology Nutrition 2012;55(6):733-735.

https://doi.org/10.1097/MPG.0b013e31826531f6

\section{ASSOCIATION BETWEEN CELIAC DISEASE AND TYPE 1 DIABETES MELLITUS: LITERATURE REVIEW}

\section{K. Antanavičiūtė, R. Šarkūnaitè}

Keywords: Celiac disease and type 1 diabetes, co-existance, prevalence, treatment, glutenfree diet.

Summary

Celiac disease is an autoimmune disease that primarily affects small intestine, related with $\mathrm{Th}-1$ lymphocytes hyperreaction to protein called gliadin that is found in wheat, rye and barley which causes villous atrophy, crypt hyperplasia and malabsorbtion. It has been found that people with celiac disease are prone to have Type 1
Diabetes Mellitus (DM), because both diseases are based on similar genetic origin. Prevalence of celiac disease among Type 1 DM patients in the world is from 5 to 16 times higher compared to an overall population. Celiac disease is usually asymptomatic in patients with Type $1 \mathrm{DM}$, but, if celiac disease is treated improperly, there is a higher risk of poor glycemic control, cardiovascular diseases and there is a greater risk for diabetes complications at younger age. Currently the common ground in diagnosing and treating celiac disease within Type 1 DM patients is still not reached. Celiac disease treatment is a lifelong gluten-free diet and this treatment is also recommended for patients with these co-existing diseases, but patients with type $1 \mathrm{DM}$ have to be supervised by dietary and endocrinology professionals.

Aim: to analyse the association between celiac disease and Type 1 Diabetes Mellitus described in various scientific literature.

Methods: the review of literature was conducted using the $\mathrm{Pu}-$ bMed, ScienceDirect and selecting publications investigating celiac disease and Type 1 Diabetes Mellitus. A total of 23 articles were selected and analyzed.

Results: studies confirmed the prevalence of celiac disease is higher in patients with Type 1 Diabetes Mellitus compared with general population.

Correspondence to: kamile.antanaviciute@gmail.com

Gauta 2021-04-22 